IZA DP No. 4902

The Cult of Theoi:

Economic Uncertainty and Religion

Paul Frijters

Juan D. Barón

April 2010 


\title{
The Cult of Theoi: Economic Uncertainty and Religion
}

\author{
Paul Frijters \\ University of Queensland \\ and IZA
}

Juan D. Barón

Australian National University, Central Bank of Colombia and IZA

\section{Discussion Paper No. 4902 \\ April 2010}

\section{IZA}

P.O. Box 7240

53072 Bonn

Germany

Phone: +49-228-3894-0

Fax: +49-228-3894-180

E-mail: iza@iza.org

Any opinions expressed here are those of the author(s) and not those of IZA. Research published in this series may include views on policy, but the institute itself takes no institutional policy positions.

The Institute for the Study of Labor (IZA) in Bonn is a local and virtual international research center and a place of communication between science, politics and business. IZA is an independent nonprofit organization supported by Deutsche Post Foundation. The center is associated with the University of Bonn and offers a stimulating research environment through its international network, workshops and conferences, data service, project support, research visits and doctoral program. IZA engages in (i) original and internationally competitive research in all fields of labor economics, (ii) development of policy concepts, and (iii) dissemination of research results and concepts to the interested public.

IZA Discussion Papers often represent preliminary work and are circulated to encourage discussion. Citation of such a paper should account for its provisional character. A revised version may be available directly from the author. 
IZA Discussion Paper No. 4902

April 2010

\section{ABSTRACT \\ The Cult of Theoi: Economic Uncertainty and Religion*}

Sacrifices to deities occur in nearly all known religions. In this paper, we report on our attempts to elicit this type of religious behaviour towards "Theoi" in the laboratory. The theory we test is that, when faced with uncertainty, individuals attempt to engage in a reciprocal contract with the source of uncertainty by sacrificing towards it. In our experiments, we create the situation whereby individuals face an uncertain economic payback due to "Theoi" and we allow participants to sacrifice towards this entity. Aggregate sacrifices amongst participants are over $30 \%$ of all takings, increase with the level of humanistic labelling of Theoi and decrease when participants share information or when the level of uncertainty is lower. The findings imply that under circumstances of high uncertainty people are willing to sacrifice large portions of their income even when this has no discernable effect on outcomes.

JEL Classification: D8, Z12

Keywords: $\quad$ uncertainty, religion, sacrifice, experiment

Corresponding author:

Paul Frijters

Room 609 - Level 6

Colin Clark Building (39)

School of Economics

University of Queensland

St Lucia, QLD

Australia

E-mail: p.frijters@uq.edu.au

\footnotetext{
* The authors would like to thank Gigi Foster, Robert Haveman, Markus Schaffner, Benno Torgler, Stefanie Schurer, Nikos Nikiforakis, Andrew Leigh, Hilary Gilles, Bill Harbaugh, Werner Gueth and Paul Oslington for comments and discussions. We would also like to thank QUT staff and students for their help with the experiments.
} 


\section{Introduction}

In this paper we report on a set of experiments designed to mimic a core aspect of nearly all known religions: sacrifices to a deity. In modern religions, the sacrifices take the form of prayer or adherence to religious doctrine. Extreme forms include the sacrifice of one's life. Historically, sacrifices took many forms. The Ancient Greeks burnt pieces of beef as a sacrifice to the gods they wished to please (Bremmer 2007; Mikalson 2005; Price \& Kearns 2003). The Romans sacrificed fruit, cakes, wine, cattle and other domestic animals (Warrior 2006; Scheid 2003, 2007). Asking to inspire and protect their warriors, water the corn fields and protect long-distance traders, the Mayas sacrificed humans, weapons and gold ornaments by putting them into the waters of a deep sinkhole (Cogins 1992; Pringle 2008). In China, a similar ceremony of ancestor worship can still be observed where individuals burn paper money in the belief that this avoids calamities and leads to prosperity (Addison 1924; Gates 1987).

We take the religious beliefs at face value and wonder what the common economic rationale is, i.e. what would a selfish person need to believe to sacrifice to a deity? This question squarely tackles the challenge laid down by Iannaconne (1998) for economic stories about the content of religions to be based on 'rational' choice. Our hypothesis then, is that gods and spirits symbolise some source of uncertainty that matters to people and that these sacrifices are made in the hope of a return favour. This closely mirrors the classic argument by Azzi and Ehrenberg (1975) that religiosity is mainly about investments in the afterlife, implicitly presuming that individuals believe the afterlife gets better when more prior investments are made. In the above examples of Roman antiquity, Greek antiquity, Mayan civilisation and modern China these bargains were explicit: sacrifices were made in order to secure a good harvest, fertility, luck in battle, etc. In the two biggest current religions, modern Christianity and Islam, the vast majority of the adherents of these faiths bargain over life after death; those who behave well go to heaven, those who do not go to hell. In mainstream Buddhism and Hinduism (the next biggest religions), those who lead a good life go up in the hierarchy of 
animals and castes, and those who lead a bad life lose status in the hierarchy. The explicit economic theme in these cases is the reciprocity of the unknown.

It is tempting to see the same mechanism outside of recognised religion in the secular spending programs of today, each with their associated industry beneficiaries: by spending vast amounts of money on $\mathrm{X}$ our societies hope to ward off the problems associated with $\mathrm{X}$ without ever really finding out if the sacrifice helped. Depending on one's political beliefs, one might want to replace $\mathrm{X}$ with 'climate change', 'killer asteroids', 'health', or 'terrorism' (Frey 2004).

The societal cost of sacrifices is not just the sacrifice itself. The existence of sacrifices attracts religious interpreters who derive influence and wealth from their status as intermediaries between the deity and the agent, which itself can lead to an entrenched religious class (Stark, Iannaccone \& Finke 1996; Stark 1999; Dennett 2006; Newberg \& Lee 2005).

Psychologists have recently argued that our ability to believe in and have human relationships with abstract entities conveys a great evolutionary advantage because it allows us to believe in shared group identities and group goals (Boyer 2008; Burkert 1983; Wilson 2002). Our abstractive abilities would create deities out of real-life economic uncertainty, whilst our ability to humanise these abstractions would allow individuals to believe deities are reciprocal (Fehr \& Gätcher 2000). This theory, which we explicitly test, yields an indirect evolutionary rationale for sacrifices.

To validate our hypothesis we create a situation where individuals face a source of economic uncertainty about which they are fundamentally ignorant. We then allow them to decide how much they wish to sacrifice to the uncertainty, termed 'Theoi, the market maker', where in each case the truth is that there is no relationship between the amount sacrificed and the ensuing realisation of the uncertainty. By physically separating the individuals from their 
group and by reducing their interactions with actual persons to anonymous interactions, we ensure that the only gain from sacrificing would be favourable choices by the unknown.

We then run experiments with reduced or no uncertainty, where individuals can still make sacrifices, in order to see if it is truly the uncertainty that leads to sacrifices or whether sacrifices are made for other reasons like a personal emotional gain involved in the act of worship ( Dennett 2006; Newberg \& Lee 2005). In such a case uncertainty should not matter. In a second variation we change the labelling of the uncertainty from 'Theoi' to 'The weather' in order to see if anthropomorphism of the unknown mattered to the emergence of sacrifices (Boyer 2008). We finally allow participants to share information to see whether more opportunities to learn about the unknown induce lower levels of sacrifices.

Throughout, we will be mindful of the fact that one can interpret all the results in the context of a learning model in which individuals gradually learn, over time, the decision rule of the unknown Theoi entity. Within a learning context, our hypothesis is that individuals have a strong prior that the unknown behaves reciprocally and we would thus expect high initial sacrifices which reduce only slowly over time. The faster the sacrifices reduce the weaker the prior belief was and thus the weaker the overall tendency to sacrifice to the unknown.

The set-up of this paper is as follows. In the next section we review the recent economic literature on religion and the contribution of this paper therein. In the third section we describe the baseline experiment, its main variations and the general story that emerges from them. In the fourth section we then use the data on the individual levels of sacrifices to look at the individual determinants of sacrifices and the most plausible learning model associated with different set-ups. The final section concludes. 


\section{The Economic literature on religion and sacrifices}

The economics of religion can be organised around four main questions: who engages in religious activities ${ }^{1}$ ? What are the costs and benefits of religion ${ }^{2}$ ? How is the market for religion organised ${ }^{3}$ ? And why do people believe what they believe? Our paper fits mainly into this last question.

\subsection{Why do people believe what they believe?}

The economic literature has produced few causal stories about the origin of actual religious beliefs. The main one is that there is an actual economic benefit to particular beliefs. The Benabou and Tirole's (2004) model takes religious beliefs to be pre-commitment devices in multi-time period models with mentally weak agents. The basic structure of their model is that individuals are fully rational in some initial period where these individuals know that in future periods they will not be able to choose optimally without some pre-commitment (because of imperfect memories, hyperbolic discounting, or a variety of other cognitive biases). Individuals can then choose in the initial period to believe in an afterlife that demands high work effort in the second period. Individuals in the second period then indeed truly believe in an afterlife and act as if they believe it. Added to this actual material self-interest of a belief is Benabou and Tirole's (2006) assertion that individuals are naturally prone to believe in the inherent justness of the world: 'the nearly universal human tendency to want to

\footnotetext{
${ }^{1}$ Iannaconne (1998); Guiso et al. (2005).

${ }^{2}$ Azzi and Ehrenberg's (1975); Gruber and Hungerman (2006); Iannaconne (1998); Iannaconne and Berman (2006); Guiso et al. (2005); Gruber (2005); Tan and Vogel (2008); Hilary and Hui (2009); Noland (2005); Becker and Wossman (2009); Ahmed and Salas (2009);

${ }^{3}$ Iannaconne and Berman (2006); Frey and Stutzer (2004); Ekelund (1996); Barros and Garoupa (2002); Hungerman (2005); Oslington (2003).
} 
believe that the world is just in the sense that people generally get what they deserve. Many experiments thus show how individuals systematically construe what they observe so as to preserve this belief - ignoring, distorting, forgetting or explaining away any information that threatens it'. This might also be interpreted as an inherent belief in the reciprocity of the unknown. In a way, our experiments try to find the mechanisms for this belief.

In a very similar vein of looking for pre-commitment benefits of religion, Blum and Dudley (2001) argue that the theory of predestination in Protestantism leads individuals to be more trustworthy, which they argue is particularly important for network-based economic growth such as small-scale commerce and industry in the Northern Europe of the $18^{\text {th }}$ and $19^{\text {th }}$ century. Again, this is a view of religious beliefs as being either the result of or at least perpetuated by economic incentives, echoing the opinions of Lewis (1955) who saw religious content as 'probably' being ultimately driven by economic forces.

Caplan (2001) interprets the contents of religious beliefs (and various other beliefs) as being mainly a matter of choice and dependent on proclivities which he doesn't further analyse or expand upon. He analyses how it is possible that people believe things that are mutually inconsistent. Individuals in his story choose their 'bliss belief' because there are almost no private costs for them if they are wrong and hence there is no incentive to believe anything more rational. They are thus rationally irrational. Caplan detects this phenomenon in the prejudices of juries, in the political beliefs of the US population and in religious beliefs. A particular aspect of Caplan's view of beliefs is that his agents hold these with absolute certainty (and claim to do so in surveys), easily ignoring or disregarding mountains of contrary evidence. Yet they are able to temporarily suspend their religious beliefs as soon as their true private interests would be threatened by the logical consequences of these beliefs. Witness in this regard the observation of Mosca (1939) which Caplan quotes approvingly: 
'Mohammed, for instance, promises paradise to all who fall in a holy war. Now if every believer were to guide his conduct by that assurance in the Koran, every time a Mohammeddan army found itself faced by unbelievers it ought either to conquer or to fall to the last man. It cannot be denied that a certain number of individuals do live up to the letter of the Prophet's word, but as between defeat and death followed by eternal bliss, the majority of Mohammedans normally elect defeat' (Mosca 1939, 181-182)

Both Mosca and Caplan maintain that the majority of the population have only superficial faith in what they profess to believe, whilst 'a minority of adherents can pressure others into pretending to share their view'. Note that if this interpretation of religious beliefs is correct, as soon as individuals are faced with the true private costs of their beliefs they should revert to more rational actions, i.e. few 'really' believe and hence few should sacrifice anything if they know no-one else is watching, which is counter to what we expect to see in our experiments.

Finally, Iannaconne and Berman (2006) propose a very definite theory of the existence of sacrifices that is perpendicular, though not mutually exclusive, to our story. In their view, sacrifices are a means of 'screening out half-hearted members and inducing higher levels of participation amongst those who remain'. Iannaconne and Berman (2006) thus interpret sacrifices as being enforced by religious entrepreneurs as an entry barrier into sects that offer a package of goods, including religious and public goods, to small communities whose public goods are not met by secular authorities. Our argument, that sacrifices are driven by economic uncertainty and can exist at the individual level without any religious community because they correspond to in-built human psychological traits, leads to falsifiable predictions not present in the argument of Iannaconne and Berman (2006). According to our theory, the level of sacrifices should go up with the level of uncertainty, a prediction not generated by the community-based story of Iannaconne and Berman (2006). 


\section{A descriptive economic framework for sacrifices}

We envisage the utility function of participant $i$ when dealing with the unknown (Theoi) to be purely guided by material self-interest, i.e. the participant maximizes

$$
\operatorname{Max}_{s} E\left(U_{i}\right)=\left(x_{i}-s\right) * p_{\text {Theoi }}(s)
$$

Here s denotes the level of sacrifice, $\mathrm{x}_{\mathrm{i}}$ denotes the number of goods initially available, and $p_{\text {Theoi }}(s)$ is the price Theoi decides upon as a function of $s$. The important part here is the beliefs an individual has about the utility function of Theoi. Allowing for the notion that Theoi is inherently reciprocal with unknown strength, we envisage the following general presumed utility function of Theoi:

$$
U_{\text {Theoi }}=s-c^{*} p_{\text {Theoi }}+f\left(p_{\text {Theoi }}-b^{*} s\right)
$$

Where $\mathrm{c}$ is the marginal cost to Theoi of giving a high level of prices (this need not mean that the unknown has a marginal value of effort; it could simply be the shadow price of the reputation of the unknown for being hard to please), and $f($.$) is presumed to be concave,$ capturing the notion of reciprocity. This leads to an optimal choice by Theoi equal to

$$
p_{\text {Theoi }}=\operatorname{Max}\left(0, \arg _{p}\left\{c=f^{\prime}\left(p-b^{*} s\right)\right\}\right)
$$

Conversely, this means an individual's optimal choice of s (conditional on expecting a positive price) would be

$$
s=\max \left\{0, \frac{x_{i} b-f^{\prime-1}(c)}{2 b}\right\}
$$

Which implicitly makes s increasing in c and increasing in b. One can think of many learning strategies that individuals may have concerning $c, b$, and $\mathrm{f}($.$) , and one can think of many$ extensions to this believed utility function. We will simply note that should individuals believe $b$ to be zero or even negative, i.e. the unknown is not reciprocal at all, then an 
individual's optimal choice of s would be zero. We will interpret a high and persistent level of $\mathrm{s}$ as a strong belief that the unknown is reciprocal ${ }^{4}$, whilst we will interpret fast declines in $\mathrm{s}$ as evidence that individuals quickly learn about the actual utility function of the unknown and thus only hold their initial beliefs very weakly.

\section{The experiments}

In total we had 393 students from the Queensland University of Technology, Australia, participate in 25 sessions during which they were anonymous to each other. In order to ensure the students had no prior interaction and that we were not picking up some peculiarity of a specific discipline, students were deliberately taken from a variety of disciplines, including accounting, finance, economics, business, information technology, engineering and architecture.

Each experiment consisted of 20 rounds of play, with a minimum of 9 and a maximum of 19 participants. In each round of play, participants earned money, where they received their cumulative winnings at the end of the experiment. The average length of a session was around 50 minutes, and the average amount paid was 23.96 Australian dollars, about twice the

\footnotetext{
${ }^{4}$ An observationally equivalent way to interpret this set-up is to think of this situation in terms of 'Pascal's wager', which denotes the idea that an individual chooses to follow the strictures of a religion on the off-chance that it might be true. The key element within 'Pascal's wager' that makes a person sacrifice is that the hypothesised believed deity actually cares about sacrifices (rather than anything of a thousand other actions one might hypothesise a deity cares about). Within our set-up Pascal's wager can simply be understood as uncertainty about the elements of Theoi's decision function, but where one would still need a prior belief in the reciprocity of the deity in order to rationalise sacrifices.
} 
minimum wage in Australia. The experiment was programmed and conducted with the software z-Tree (Fischbacher 2007).

In the baseline experiment each round consisted of two phases: (i) a standard public good game with a Voluntary Contribution Mechanism, and (ii) the sacrifice towards the uncertainty. At the start of Phase I, each individual was given 100 tokens. Participants were told that these represent units of a good. They were given the opportunity to invest between 0 and 100 units to a group project. The total amount invested by the group was multiplied by 1.6 and then divided equally among the group members regardless of individual contributions. Each participant's total holdings of the good at the end of Phase I was obtained by adding up the units they get from the group project (net of their individual investment) to the units they chose not to invest. The optimal joint outcome was for each participant to invest 100 , in which case each gets back 160. The optimal outcome for a selfish individual arose if the others contributed a 100 and he contributed nothing.

At the end of Phase I, each individual would have a positive amount of units of the good. In Phase II (the sacrifice towards uncertainty), each individual was told that "Theoi", "the market Maker', decides on the actual monetary value of the good earned in Phase I. Participants were deliberately kept ignorant about Theoi's decision rule and were simply told that the way Theoi decides is unknown. Participants were then given the option to 'contribute' any number of units of the good between 0 and what they earned in Phase I to Theoi. ${ }^{5}$ After this

\footnotetext{
${ }^{5}$ The use of the word 'contribute' is deliberate. Alternative wordings could have been 'sacrifice', 'allocate', 'give', etc. The choice of the word 'contribute' is because of its multi-interpretable nature, i.e. it is possible to 'contribute' to something whilst either expecting something in return or not expecting something in return. To 'give' would usually imply expecting no reward, whilst to 'allocate' is a word with the same ambiguity as 'contribute' ('to allocate' can mean both 'to invest' or 'to give') but as a word is infrequently used amongst noneconomist. Whilst the direct use of the word 'sacrifice' would also allow ambiguity, it would naturally be interpreted within a scientific experiment setting as 'give away whilst expecting nothing in return'.
} 
contribution they were informed about the monetary value of the good as decided by Theoi and their total income for the round. Their total income for the round (in experimental currency units, ECU) was calculated as Phase I units of the good (net of the units sacrificed to Theoi) times the unit value of the good determined by Theoi. ECUs were converted to real (Australian) dollars using an exchange rate of 1 dollar for each 100 ECUs. After recording this value, a new round would begin.

In the baseline experiment the actual decision rule Theoi follows was entirely random as it equalled Unit Value $=\max (0,1+$ individual shock + group shock $)$. In this expression both the individual shock and the group shock are distributed uniformly on the $(-1,1)$ interval. Furthermore, the group shocks in periods 5,10 , and 15 were rigged to be particularly negative in that the group shocks were put at -0.5 in those periods. We deliberately used both individual and group shocks to make it difficult for the participants to work out (after the experiments) what the precise mechanism would have been, yet simple enough so that they could reasonably learn within 20 periods that their sacrifices had no effect on Theoi.

Phase I of each round was mainly intended to give the participants a sense of ownership over the money they play with in Phase II. Phase I could in principle be replaced by any other standard economic game that involves reciprocity or altruism (Güth, Schmittberger \& Schwarze 1982; Fehr \& Fischbacher 2003; Andreoni, Harbaugh \& Vesterlund 2008) and our choice of Phase I was mainly predicated by a desire to be able to compare some aspects of our experiment to existing literature. An important robustness check was to replace Phase I by a math test in which individuals could earn goods.

In total, 56 individuals participated in the baseline experiment. The level invested in Phase I was very similar to that found in other countries (Figure 1, panel a). The average percentage investment of $34.9 \%$ in these experiments compares to positive contributions to the public good found in similar studies (Ledyard 195; Keser \& van Winden 2000; Croson 2008). Another standard finding was that, given that there is no enforcement mechanism, the 
contribution to the public good generally declined over time as individuals behaved more selfishly (Fehr \& Gätcher 2000, 2000, 2003). These standard results mean there was nothing overtly strange about our pool of participants.

Figure 1 (panel b) shows the results of Phase II, the average proportion of units earned in Phase I sacrificed to Theoi. What is striking is the very high levels of sacrifices made: individuals started off sacrificing about half their winning to the source of uncertainty, almost as if they were sharing 50-50 with the unknown entity. The level sacrificed dropped over time, but was not significantly lower after 18 periods ( mean $=0.33, S D=0.31)$ than after 8 ( mean $=0.26, S D=0.24 ; t(110)=-1.32, P=0.19)$. Rather, it hovered between $23 \%$ and $33 \%$ with an average for the last five periods of $27.3 \%$ (clustered $S E=0.027$ ). Hence even in the long run, considering all 20 rounds, individuals on average sacrificed around $30.0 \%$ ( $S E=0.025$ ) of what they obtained in Phase I. If we disaggregate this, we find that in the last five periods, $92.9 \%$ (or 52 out of 56) of participants sacrificed on average a positive amount, with $69.6 \%$ sacrificing more than $10 \%$ on average of their Phase I winnings in the last five periods.

The sacrificial behaviour following the negative aggregate shocks of period 5, 10, and 15 do not follow any discernible trend; aggregate sacrifices dropped between period 5 and 7 , whilst they increased between period 15 and 17.

Table 1 describes the results of the baseline experiment and that of all the 3 different main treatments. We will discuss these different treatments that are important to our main argument, and then quickly discuss the other, more robustness oriented treatments. 


\subsection{Do you really need uncertainty to see sacrifices?}

Our first set of additional experiments was designed to test whether uncertainty truly is a crucial step to get sustained high sacrifices. In the first set of alternative treatments, applied to 65 participants in three sessions, we re-ran the baseline experiments without any uncertainty, that is, we made the unit value always equal to 1 (see treatment 2 in Table 1). The results for Phase I were once again standard and not shown here. The results for Phase II are in Figure 2 which shows the levels of sacrifices for the baseline experiment and the no-uncertainty case.

Amongst the no-uncertainty group, the aggregate level of sacrifice in the last five periods was only $7.36 \%$ ( $S E=0.016$ ), which was one-fourth of that in the baseline experiment with uncertainty $($ mean $=27.3 \%, S E=0.027)$. The p-value for a test of means in each period rejects the null hypothesis of the equality of these means in all last 5 periods at the $5 \%$ level of significance. Hence, whilst a small number of participants kept sacrificing something, the participants were clearly not just sacrificing because the option to do so existed. The majority clearly did learn that the unknown was not reciprocal. One might think that those who still contributed positively never varied their sacrifice and hence did not have time to learn. However, this is not the case because no individual sacrificed the same amount in all 20 periods. Whilst only 25 out of 65 sacrificed more in the last 5 periods than a minimal amount (more than 2\%), these 25 individuals on aggregate sacrificed some 18.5\% of their takings on average, which does not significantly differ from the sacrifices in the baseline experiment. The fact that some individuals seem impervious to feed-back when it comes to sacrificing is commensurate with hypotheses about of the existence of 'types' of individuals who differ in their level of reciprocity behaviour (Fehr \& Gätcher 2000).

\subsection{Does the uncertainty need a human name to sustain sacrifices?}

A further hypothesis we wished to test is whether it matters how we label the source of uncertainty. Our working assumption was that giving a human name (Theoi) to the source of uncertainty would elicit higher sacrificial behaviour than if we would adopt a labelling that, 
within the culture of Australia, would be associated with something usually outside the sphere of influence of individuals. To this end, we performed experiments with 32 participants (in 2 sessions) where the name Theoi was substituted by 'the weather'. Participants were told that the weather was responsible for the unit values and that it was unknown how the weather affected the unit value of the good. Otherwise, the parameters were exactly equal to the baseline experiment (see Table 1, treatment 3). Once again, the level of contribution to the public good was standard so we do not show them here.

Phase II results are consistent with our working hypothesis that labelling matters (Figure 3). The initial level of sacrifice was similar ( mean $=0.373, S D=0.249$ ) to the initial level of the baseline experiment $($ mean $=0.389, S D=0.297 ; t(86)=-0.280, P=0.790)$, and dropped till an average of 0.187 (clustered $S E=0.025$ ) in the last five periods, which is about a quarter lower than that of the baseline experiment ( mean $=0.273, S D=0.027 ; t(86)=2.13, P=0.036$ ). Interestingly, in these experiments only $37.5 \%$ of individuals sacrificed less than $10 \%$ on average in the last five periods.

We might mention that these results also show that it is not just learning that is going on in these experiments: because the actual pay-off rule is exactly the same in this experiment as in the baseline, the learning effect should also be the same. Rather, the labelling itself affects the prior belief about the actions of the unknown.

\subsection{Does more information break religion?}

The final hypothesis we examined was that the level of sacrifices would reduce if individuals were given more information about the level of sacrifices and the unit values of other participants (see Table 1, treatment 4). A key question was whether some individuals would ignore the information and sacrifice anyway or whether all the participants would take the opportunity to learn from other decisions Theoi made. 
To this end, we gave all participants in Phase II of each round the option to reveal their Phase I sacrifice to Theoi as well as the unit value they were then hit by (53 individuals in 3 sessions). On average, $64.3 \%$ of participants in each round shared information, increasing from $56.6 \%$ in the first round to $66.0 \%$ in the last round. These sessions lasted slightly longer than an hour, as some participants spent extra time analysing the information shared by others (the baseline session lasted 50 minutes).

In this experiment, the aggregate level of sacrifices in the last 5 periods ( mean $=0.187, S E=0.025)$ was again significantly below that of the baseline experiment $($ mean $=0.273, S E=0.027 ; t(86)=2.126, P=0.034)$. Compare Figure 1 (panel $b)$ to Figure 4. At $17.9 \%$ ( $S E=0.024$ ), aggregate sacrifices, however, were the same in the last five periods of this experiment as they were when we labelled the uncertainty as 'the weather' in experiment 3 (mean $=0.187, S E=0.025 ; t(83)=-0.219, P=0.827)$. If we then look at individual levels, we find that $62.3 \%$ of participants sacrificed more than $10 \%$ of their Phase I holdings of the good in the last five periods. This means that the vast majority kept on sacrificing large amounts even though they had access to an average of about 250 sacrificeaward observations.

These information experiments are the clearest indication that learning from the experience of others, although it is certainly present, is extremely slow. Aggregate sacrifices in a round remain tightly anchored to the initial belief, even after 200 sacrifice-award observations. A tempting hypothesis is that many individuals simply do not bother to put in the effort to learn about the actual reciprocity of the unknown and instead trust their prior on this. Indeed, one could see this during the experiments: typically about 3 or 4 out of the 20 would stare at their screens to try and work out what was going on whilst the majority quickly made up their minds, only glancing at the additional information provided to them. It may of course be true that there was simply not enough at stake for most participants to bother to update their initial beliefs by analysing new information, though we may here already foreshadow that those few 
participants who spent more time analysing the data did not sacrifice significantly less (see next section).

\subsection{Robustness treatments}

We ran additional treatments to test particular alternative hypotheses concerning sacrifices (see Table 2). Our main concern was whether our results were an artefact of our design. In total, some 187 students were involved in these experiments. Briefly described, the robustness experiments tackled the following questions:

- Are the Phase II results an artefact of the Phase I design? One might argue that Phase I primes individuals to expect Theoi to be human and reciprocal because Phase I was itself related to reciprocity. In order to investigate this, we ran 4 more sessions on 72 subjects in which Phase I was replaced by simple mathematical tests via which individuals could earn units. These mathematical tests consisted of five sums of positive, 1-digit numbers; fours sums of positive, 2-digit numbers; and 3 sums of positive, 3-digit numbers. In total, subject where presented with these 12 sums at the same time and they had 45 seconds to answer as many as they could. Each correct answer will award the subject 20 tokens (units of the good). In addition, 20 more tokens were given to each subject to avoid having subjects starting Phase II with no tokens. Table 2 (robustness treatment 1) shows the other details of this treatment. On average for all sessions and periods, subjects solved $6.36(\mathrm{SD}=1.75)$ problems correctly, which gave them an average of Phase I's units of the good of 147.25 $(\mathrm{SD}=34.99)$. The level of this Phase I outcome is similar to the units obtained by participants in all other sessions where Phase I consisted of the public good game with the Voluntary Contribution Scheme (the average was 121.56, $\mathrm{SD}=31.46$ ). The profile of sacrifice does not change when compared to the baseline treatment, and as was the 
case in the baseline treatment, subjects sacrificed around $30 \%$ of their holdings from Phase I (mean $=0.322$; clustered $\mathrm{SE}=0.027$ ) in the last five periods.

- Would individuals sacrifice less if they were prompted a low amount? In order to investigate this, we added a default level of sacrifice equal to $10 \%$ that would automatically appear on the screen. Hence individuals had to remove the $10 \%$ and enter a different amount if they did not want to sacrifice 10\%. Again, this made no difference to the level or profile of the sacrifices, implying that the average participant indeed actively removed the prompted amount and substituted it with higher amounts. In the last five periods the average sacrificed was $23.8 \%$ (clustered $S E=0.063$ ).

- Would it help if there was actually a negative $\backslash$ positive feedback between sacrifices and outcome? In order to investigate this possibility, we varied Theoi's decision rule. In one session we allowed a positive association between sacrificing unit to Theoi and the unit vale. Specifically, if the subject sacrificed something, his unit value was determined by 1 plus a random number uniformly distributed between 0 and 1 . On the other hand, if the subject sacrificed nothing, his unit value was determined by 1 minus a random number uniformly distributed between 0 and 1 (see Table 2, robustness treatment 3). In another session, there was a negative association between sacrifice and unit value. If the subject sacrificed something, it would receive a negative random shock to the unit value, and if he decided to sacrifice nothing, then a positive random shock would affect his unit value in a similar fashion to the positive association case just described (see Table 2, robustness treatment 4). In this case we found that individuals sacrificed more on average when the correlation was negative and less when it was positive, exactly opposite to what one would expect from a rational point of view. However, only twelve subjects participated in each of these two sessions, and hence, results should be taken with caution. 
- The next hypothesis we wished to test was whether having sacrifices to a single source provided a benefit to the group as a whole. In our context, this meant we wondered whether the contribution to the public good made in Phase I would be higher with sacrifices than if there was no option to sacrifice (see Table 2, treatment 6). To this end, we simply performed 3 sessions with 49 subjects in total who played Phase I but not Phase II. Unit values were still subject to the random shocks but individuals were merely informed of these shocks without having a sacrifice option. We find that aggregate contributions to the public good are slightly lower without sacrifices than they are with sacrifices in the last 5 periods. The aggregate contribution is 41.91 , which is not significantly different at the $10 \%$ level from the average of 45.78 of the baseline experiment. Hence, our individualised option to sacrifice has no discernible effect on feelings of group solidarity in the sense of bigger contributions to the public good. 


\section{Individual determinants of sacrifices}

At the end of each experiment we asked individuals to give us their personal characteristics, including their level of religiosity, their health, and their incomes. The sample averages for all experiments combined are reported in Table 2. We run simple Tobit models on the individual determinants of the proportion sacrificed in Table 3.

The columns in Table 3 gradually add more variables, such that columns 3 and 7 show 'kitchen sink regressions'. The difference between the columns 1 to 3 and the columns 4 to 7 is that the later columns also include interactions between the period number and the variables.

In the first specification, all that are included are 4 variables capturing the time-profile (the inverse of the period and 3 time dummies following the negative shocks) and the contribution to the public good game in Phase I. Apart from these variables, all specifications include dummies for the type of treatment.

In the first column, we see that a large part of the initial sacrifice $(0.2287)$ is predicted to eventually go to zero as the number of periods tends to infinity. This part is almost half of the initial sacrifice. This fraction goes down as more variables are added over the columns, such that in the 'kitchen sink' regression of column 7, only 0.11 of the initial level of sacrifice is predicted to go to zero. The results in the first column also reveal no effect of the two later 'negative shock periods 11 and 16', though there is a significant positive increase in sacrifices after the first major negative shock, i.e. the level of sacrifice in period 6 is 0.05 higher than otherwise predicted. The importance of the level of contributions in the first period is also shown to be great: an individual contributing $100 \%$ to the initial public good game sacrifices a 0.39 fraction more than an individual who sacrifices nothing in the initial public good game. This indicates that the expectation of reciprocity may indeed be a strong individual personality trait.

Looking at the effect of other variables in the subsequent columns, we find that the older significantly sacrifice more which echoes the usual finding for normal religious behaviour (Iannaconne 1998). Interestingly, the level of own reported religiosity has no marked effect on 
the level of sacrifice, suggesting that religious tendencies are not confined to recognised religion. We also see, surprisingly, that students of engineering and IT sacrifice significantly more, whilst students of economics sacrifice just as much as the default (mainly arts and business).

Variables that pick up an individual's stated degree of superstition (measured by the belief in good luck charms), marital status, and satisfaction with finances or life, have no significant impact on the level of sacrifice.

In column 4 we see that the interaction between period and the level of contributions in the first Phase is significantly negative, which indicates that individuals contributing more in the first Phase more strongly reduce their contributions over time, which makes sense as they contributed more to begin with. From the interactions in column 5 to 7 , we see that females significantly increase their contributions over time relative to men, that those with lucky charms significantly reduce their contributions over time, and that those with a high locus of control significantly reduce their sacrifices over time. Unexpectedly, those who take more time to decide on how much to sacrifice to Theoi significantly increase their contributions over time compared to those who decide more quickly. One interpretation of these findings is that men, those with good luck charms, with high locus of control, and those who take little time in deciding, are the ones who learn faster about the non-reciprocity of Theoi. It is the case that these interactions combined are significant.

The most salient finding in this table remains the coefficient on the contribution made to the public good. This is highly positive, indicating that reciprocity towards the public good complements rather than substitutes for expected reciprocity towards the unknown.

\section{Conclusions}

In this paper we found that individuals sacrifice towards a source of economic uncertainty and that they sacrifice more when the uncertainty is higher and when it has a human name. Our interpretation is that, when faced with an incomprehensible phenomenon, individuals anthropomorphise the unknown (Boyer 2008). They could do this because the unknown is 
seen as powerful and hence necessarily 'at least equal to' humans. A variant of this hypothesis is that humanising the unknown is the quickest mental strategy available that requires less mental effort than close observation of the unknown and its actions. The unknown would then be presumed to be reciprocal because humans are often reciprocal. This extends the arguments about the innate reciprocity of humans to the realm of the metaphysical (Fehr \& Fischbacher 2003; Croson 2007).

One interesting strand of future research is the notion of lock-in mechanisms. Intermediaries who control the information provided to the population about the source of uncertainty might be instrumental in transforming sacrifices that start as bargains with the unknown into elaborate religions. It is also possible that sacrificing towards the unknown gives a direct intrinsic reward in the form of stress-relief, as if giving the unknown 'its due' makes individuals feel they have squared an internal mental balance (Dennett 2006; Newberg \& Lee 2005). The importance of such competing lock-in mechanisms for the persistence of religion seems a promising next step in the search for economic explanations of modern-day religions.

Suppose the train of thought in this paper holds. In what way does the emerging view of religion then differ from the current view in the economics of religion? For the most part, our views fit snugly with most of those of Iannaconne and Berman (2006). Organised religion, which minimally includes an intermediary role between the innate wish for certainty and the ultimate suppliers (the reciprocal supernatural entities), would itself constitute a rent and be susceptible to the usual market forces. The story of religion would itself be mainly guided by whatever sources of uncertainty populations experience and thus economic 'fundamentals' would have the primacy, just as in the theories of Lewis (1955). As in Iannaconne and Berman (2006), sects and religious organisations would be rival providers of public goods (imaginary or true) and religions would be predicted to lessen in levels of activity and fervour if secular states would provide more public goods. 
Where our view subtly differs is that it is predictive of the content of religion by giving reasons for the actual religious stories doing the rounds, bound as they are by sources of important uncertainty. Indeed, our view is predictive of new religions as new sources of uncertainty are recognised and played out in the media, such as uncertainty in global climate patterns. Not only do we provide a predictive story for new religions, but we furthermore do not rely on religious stories to be pre-commitment devices for other things of actual importance, such as providing sufficient work effort which is the essence of the Benabou and Tirole (2004) models and other models of the afterlife as a pre-commitment device to do what is already in one's own interest (e.g. Ahmed and Salas 2009). In our view, to sacrifice is not in one's own rational material interests, unless of course the uncertain truly is reciprocal.

Where our study strongly differs is in the interpretation of sacrifices, which Iannaconne and Berman (2006) interpret as entry-barriers that help enforce high public goods provisions within small clubs. Instead we interpret sacrifices as part of the direct trade between the unknown and individuals, a trade that is capable of surviving even in the absence of communities or other outside benefits. Our individual-level experiments were set up to discount community benefits of sacrifices, and to us it does not really seem to make much sense to view sacrifices as club-entry devices. If religious clubs indeed have a need for entry barriers, then why would they include sacrifices which only have costs to both individuals and the community (such as suicides or the burning of food)? Rather, wouldn't it make more sense to have individuals observably sacrifice their time to observable public goods, as many religious communities indeed do in the form of charity to the poor? Other forms of entry barriers are equally easy to think of, implying that our theory views sacrifices as innate to the production of certain religious goods. This doesn't mean however that there is no relationship between sacrifices and entry barriers. Precisely because individuals are prone to believe sacrifices work, visible true sacrifices do flag adherence to beliefs and thereby confer value as a means of screening out the less-believing. However, the primacy here is the religious content and the level of uncertainty facing a community. The possibility that a sect could 
overcome the uncertainty in some spheres (education, health, child care) is secondary: there would be a high level of demand to sacrifice anyway in situations of high uncertainty. 


\section{Bibliography}

Addison, J. 1924. The modern Chinese cult of ancestors. J. Religion 4, 492-503.

Ahmed, Ali M., and Osvaldo Salas (2009). 'Is the hand of god involved in human cooperation?', International Journal of Social Economics 36, pp. 70-80.

Andreoni, J., Harbaugh, W. \& L. Vesterlund. 2008. Altruism in experiments. In The New Palgrave Dictionary of Economics, S. Durlauf \& L. Blume (Palgrave Mcmillan, Second edition).

Azzi, C. and R. Ehrenberg (1975), 'Household allocation of time and church attendance', Journal of Political Economy 83, pp. 27-56.

Barros, P. P. and N. Garoupa (2002), 'An economic theory of church strictness', Economic Journal, vol. 112(481), pages 559-576.

Beauregard, M. \& V. Paquette. 2006. Neural correlates of a mystical experience in Carmelite nuns. Neuroscience Letters 405, 186-190.

Benabou, R. and J. Tirole. 2004. 'Belief in a just world and redistributive policies', Quarterly Journal of Economics, vol. 121(2), pages 699-746.

Becker, S. O. and L. Wossman. 2009. 'Was Weber wrong? A human capital theory of protestant economic history?', Quarterly Journal of Economics.

Blum, U. and L. Dudley (2001), 'Religion and economic growth: was Weber right?', Journal of Evolutionary Economics 11, pp. 207-30.

Boyer, P. 2008. Being Human: religion: bound to believe? Nature 445, 1038-39

Bremmer, J. 2007. Normative Animal Sacrifice. In A Companion to Greek Religion, D. Ogden, Ed. (Blackwell Publishing, Malden, MA, 2007), 132-144.

Burkert, W. 1983. Homo Necans: The Anthropology of Ancient Greek Sacrificial Ritual and Myth University of California Press, Berkeley.

Caplan, B. (2001), 'Rational ignorance vs. rational irrationality', Kyklos 54 (1), pp. 3-26.

Cogins, C. (Ed.) 1992. Artifacts from the cenote of sacrifice: Chichen Itza, Yucatan. Memoirs of the Peabody Museum of Archaeology \& Ethnology, Harvard University 10.

Croson, R. 2008. Public goods experiments. In The New Palgrave Dictionary of Economics, S. Durlauf \& L. Blume Palgrave Mcmillan, Second edition.

Croson, R. 2007. Theories of commitment, altruism and reciprocity. Evidence from linear public good games. Econ. Inquiry 45, 199-216.

Davis, D. \& C. Holt. 1993. Experimental Econ. (Princeton University Press, Princeton, NJ. 
Dennett, D. 2006. Breaking the Spell. Penguin Books, London.

Ekelund, R. B. (1996), Sacred trust: the medieval church as an economic firm. Oxford University Press.

Fehr, E. \& U. Fischbacher. 2003. The nature of human altruism. Nature 425, 785-791.

Fehr, E. \& S. Gätcher. 2000. Cooperation and punishment in public good experiments. Amer. Econ. Rev. 90, 980-994.

Fehr, E. \& S. Gätcher. 2000. Fairness and retaliation: the economics of reciprocity. J. Econ. Perspect. 14, 159-181.

Fischbacher, U. 2007. Zurich Toolbox for Ready-made Economic Experiments. Experimental Econ. 10, 171-178.

Frey, B.S. 2004. Dealing with Terrorism: Stick Or Carrot? (Edward Elgar, Cheltenham, UK).

Gates, H. 1987. Money for the Gods. Modern China 13, 259-277.

Gould, S. 1999. Rocks of Ages: Science and Religion in the Fullness of Life Ballantine Pub. Group, New York.

Gruber, J. (2005), 'Religious market structure, religious participation, and outcomes: is religion good for you?', NBER Working Papers 11377.

Gruber, J. and D. Hungerman (2006), 'The church vs. the mall: what happens when religion faces increased secular competition?’, NBER Working Paper 12410.

Guiso, L., Sapienza, P., and L. Zingales (2005), 'People's opium? Religion and economic attitudes', Journal of Monetary Economics 50, pp. 225-82.

Güth, W., Schmittberger, R. \& R. Schwarze. 1982. An experimental analysis of ultimatum bargaining. J. Econ. Behavior and Organization 3, 367-388.

Gillers, H. and Hui, K. W. 2009. 'Does religion matter in corporate decision making in America?', Journal of Financial Economics 93, pp. 455-73.

Hungerman, D. M. 2005, 'Are church and state substituted? Evidence from the 1996 welfare reform', Journal of Public Economics 89, Pp. 2245-67

Iannacone, L. R. 1998. 'Introduction to the economics of religion', Journal of Economic Literature 336, pp. 1465-96.

Iannacone, L. R. and E. Berman.2006. 'Religious extremism: the good, the bad, and the deadly', Public Choice 128, pp. 109-29.

Issac, R., Walker, J. \& S. Thomas. 1984. Divergent evidence of free riding: An experimental examination of possible explanations. Public Choice 43, 113-149. 
Keser, C. \& F. van Winden. 2000. Conditional cooperation and voluntary contributions to public goods. Scand. J. Econ. 102, 23-39.

Ledyard, J. 1995. Public goods: a survey of experimental research. In The Handbook of Experimental Economics, J. Kagel \& A. Roth, Eds. Princeton University Press, Princeton, NJ, pp. 111-194.

Lewis, W.A. (1955), The theory of economic growth. Homewood, IL: Richard D. Irwin

Mosca, G. (1939), The ruling class, New York: McGraw Hill.

Mikalson, J. 2005. Ancient Greek Religion (Blackwell Publishing, Malden, MA.

Newberg, B. \& B. Lee. 2005. The neuroscientific study of religious and spiritual phenomena: or why God doesn't use biostatistics. Zygon 40, 469-489.

Noland, M. (2005), 'Religion, culture, and economic performance', World Development 33(8), pp. 1215-32

Oslington, P. (2003, ed.), Economics and Religion, Edward Elgar, I and II.

Price, S. \& E. Kearns. 2003. (Eds.) The Oxford Dictionary of Classical Myth and Religion (Oxford University Press, New York.

Pringle, H. 2008. Trade and Intrigue: The merchant prince. In Mysteries of the Maya (National Geographic, Collector's Edition, USA, 81-83).

Scheid, J. 2003. An Introduction to Roman Religion. Indiana University Press, Bloomington.

Scheid, J. Sacrifices for gods and ancestors. 2007. In A Companion to Roman Religion, J. Rüpke, Ed. Blackwell Publishing, Malden, MA, 263-271.

Stark, R. 1999. Micro foundations of religion: a revised theory. Sociological Theory 17, 264289.

Stark, R., Iannaccone, R. \& R. Finke. 1996. Religion, science, and rationality. Amer. Econ. Rev. 86, 133-437.

Tan, J. H.W., and C. Vogel (2008), 'Religion and trust: an experimental study', Journal of Economic Psychology 29, pp. 832-48.

Warrior, V. 2006. Roman Religion. Cambridge University Press, New York.

Wilson, D. 2002. Darwin's Cathedral: Evolution, Religion, and the Nature of Society University of Chicago Press, Chicago, IL. 
Figures and Tables 
Table 1. Description of main treatments

\begin{tabular}{|c|c|c|c|c|c|c|c|}
\hline Treatment & Description & Individual Shock & Group Shock & $\begin{array}{c}\text { Unit Value } \\
\text { of the Good }(\mathbf{U V})^{(a)}\end{array}$ & $\begin{array}{l}\text { Income in each Period } \\
\text { (in experimental units) }\end{array}$ & Sessions & Participants \\
\hline 1. Baseline & $\begin{array}{l}\text { Unit value of the good } \\
\text { is determined randomly } \\
\text { and sacrifice has no } \\
\text { effect. }\end{array}$ & $\begin{array}{l}\text { Random number } \\
\text { distributed uniform } \\
\text { in the interval }[0,1)\end{array}$ & $\begin{array}{c}\text { Random number } \\
\text { distributed uniform in } \\
\text { the interval }[0,1) \text {. In } \\
\text { periods } 5,10 \text {, and } 15 \\
\text { group shock equals } 0.5 \text {. }\end{array}$ & $1+$ Ind. Shock + Group Shock & UV*(Holding PI - Sacrifice) & 4 & 56 \\
\hline 2. No effect & $\begin{array}{l}\text { Unit value of the good } \\
\text { is fixed at } \$ 1 \text { and } \\
\text { sacrifice has no effect. }\end{array}$ & None & None & 1 & UV*(Holding PI - Sacrifice) & 4 & 65 \\
\hline $\begin{array}{l}\text { 3. The } \\
\text { Weather }\end{array}$ & $\begin{array}{l}\text { Unit value of the good } \\
\text { is determined randomly } \\
\text { and sacrifice has no } \\
\text { effect. "Theoi" is } \\
\text { replaced by the weather } \\
\text { everywhere. }\end{array}$ & $\begin{array}{l}\text { Random number } \\
\text { distributed uniform } \\
\text { in the interval }[0,1)\end{array}$ & $\begin{array}{l}\text { Random number } \\
\text { distributed uniform in } \\
\text { the interval }[0,1) \text {. In } \\
\text { periods } 5,10 \text {, and } 15 \\
\text { group shock equals } 0.5 \text {. }\end{array}$ & $1+$ Ind. Shock + Group Shock & UV*(Holding PI - Sacrifice) & 2 & 32 \\
\hline 4. Share info & $\begin{array}{l}\text { Unit value of the good } \\
\text { is determined randomly } \\
\text { and sacrifice has no } \\
\text { effect, but each } \\
\text { participant can reveal } \\
\text { their contribution to } \\
\text { Theoi and the unit } \\
\text { value they obtain. }\end{array}$ & $\begin{array}{l}\text { Random number } \\
\text { distributed uniform } \\
\text { in the interval }[0,1) \text {. }\end{array}$ & $\begin{array}{c}\text { Random number } \\
\text { distributed uniform in } \\
\text { the interval }[0,1) \text {. In } \\
\text { periods } 5,10 \text {, and } 15 \\
\text { group shock equals } 0.5 \text {. }\end{array}$ & $1+$ Ind. Shock + Group Shock & UV*(Holding PI - Sacrifice) & 3 & 53 \\
\hline
\end{tabular}

Notes:

* This description does not include the Part I of each treatment which is the Public Good game. Part I is exactly the same for all four treatments.

${ }^{(a)}$ Given the characteristics of the individual and group shock it is possible to randomly obtain a negative value for the Unit Value. To avoid this, the specific formula used was:

Unit Value $=\max (0,1+$ Ind Shock + Group Shock $)$. 
Table 2. Description of robustness treatments

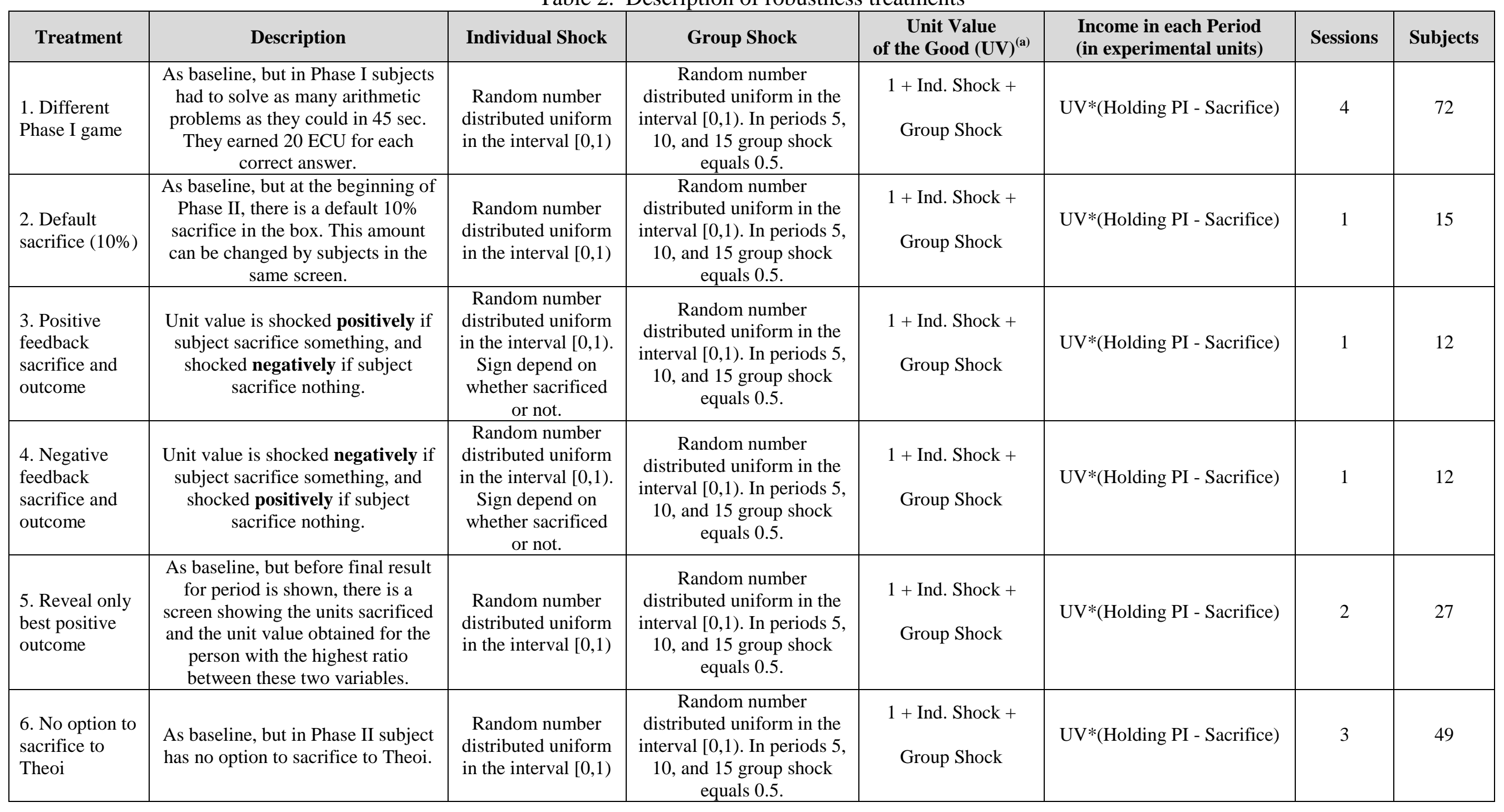


Table 3. Descriptive statistics of variables in the Tobit models

\begin{tabular}{lrrrr}
\hline Variable & \multicolumn{1}{l}{ Mean } & \multicolumn{1}{l}{ Std. Dev. } & \multicolumn{1}{l}{ Min } & \multicolumn{1}{c}{ Max } \\
\hline Contribution to PG game & 33.731 & $(33.293)$ & 0.00 & 100.00 \\
1/period & .180 & $(0.218)$ & 0.05 & 1.00 \\
Time deciding sacrifice to Theoi & 15.744 & $(7.004)$ & 1.00 & 129.00 \\
Dummy Period 6 & .050 & $(0.218)$ & 0.00 & 1.00 \\
Dummy Period 11 & .050 & $(0.218)$ & 0.00 & 1.00 \\
Dummy Period 16 & .050 & $(0.218)$ & 0.00 & 1.00 \\
Female & .476 & $(0.499)$ & 0.00 & 1.00 \\
Australian & .459 & $(0.498)$ & 0.00 & 1.00 \\
Age & 23.208 & $(5.484)$ & 17.00 & 52.00 \\
Has a lucky charm & .268 & $(0.443)$ & 0.00 & 1.00 \\
Belive someone watches over them & .553 & $(0.497)$ & 0.00 & 1.00 \\
Index: Good luck charms bring good luck & 2.707 & $(1.161)$ & 1.00 & 5.00 \\
How often person goes to church & 4.379 & $(1.609)$ & 1.00 & 6.00 \\
Relative socio-economic status & 2.194 & $(0.567)$ & 1.00 & 3.00 \\
Dummy for economists and finance students & .735 & $(0.441)$ & 0.00 & 1.00 \\
Dummy for Engineering/IT students & .177 & $(0.381)$ & 0.00 & 1.00 \\
English is main language & .567 & $(0.496)$ & 0.00 & 1.00 \\
Locus of control index & 13.336 & $(3.476)$ & 7.00 & 22.00 \\
Satisfaction with financial situation (1-10) & 5.091 & $(2.451)$ & 1.00 & 10.00 \\
Satisfaction with all thing in life & 3.729 & $(0.902)$ & 1.00 & 5.00 \\
Married & .333 & $(0.471)$ & 0.00 & 1.00 \\
\hline \hline
\end{tabular}

Standard errors in parentheses. Observations: 7020 (351 individuals in 20 periods). 
Table 4. Proportion of Phase I sacrificed to Theoi, Tobit results.

\begin{tabular}{|c|c|c|c|c|c|c|c|}
\hline Variable & Model 1 & Model 2 & Model 3 & Model 4 & Model 5 & Model 6 & Model 7 \\
\hline \multirow[t]{2}{*}{ Contribution to $\mathrm{PG}$ game } & .0039 & .0038 & .0038 & .0044 & .0038 & .0038 & .0037 \\
\hline & $(.0003)$ & $(.0003)$ & $(.0003)$ & $(.0003)$ & $(.0004)$ & $(.0004)$ & $(.0004)$ \\
\hline \multirow[t]{2}{*}{ 1/period } & .2287 & .2325 & .2320 & .1892 & .1334 & .1265 & .1110 \\
\hline & $(.0245)$ & $(.0216)$ & $(.0246)$ & $(.0216)$ & $(.0217)$ & $(.0246)$ & $(.0258)$ \\
\hline \multirow[t]{2}{*}{ Dummy Period 6} & .0501 & .0513 & .0512 & .0425 & .0257 & .0235 & .0215 \\
\hline & $(.0140)$ & $(.0132)$ & $(.0137)$ & (.0136) & $(.0140)$ & $(.0141)$ & $(.0139)$ \\
\hline \multirow[t]{2}{*}{ Dummy Period 11} & .0038 & .0038 & .0038 & .0034 & -.0027 & -.0033 & -.0021 \\
\hline & $(.0129)$ & $(.0123)$ & $(.0127)$ & $(.0130)$ & $(.0128)$ & $(.0124)$ & $(.0134)$ \\
\hline \multirow[t]{2}{*}{ Dummy Period 16} & -.0184 & -.0190 & -.0190 & -.0127 & -.0019 & -.0005 & -.0032 \\
\hline & $(.0112)$ & $(.0111)$ & $(.0114)$ & $(.0103)$ & $(.0104)$ & $(.0097)$ & $(.0106)$ \\
\hline \multirow[t]{2}{*}{ Female } & & .0238 & .0266 & & -.0121 & -.0222 & -.0194 \\
\hline & & $(.0225)$ & $(.0221)$ & & $(.0254)$ & $(.0269)$ & $(.0276)$ \\
\hline \multirow[t]{2}{*}{ Australian } & & .0248 & .0225 & & .0011 & .0061 & .0077 \\
\hline & & $(.0293)$ & $(.0292)$ & & $(.0341)$ & $(.0322)$ & $(.0335)$ \\
\hline \multirow[t]{2}{*}{ Age } & & .0038 & .0035 & & .0049 & .0030 & .0031 \\
\hline & & $(.0016)$ & $(.0019)$ & & $(.0018)$ & $(.0019)$ & $(.0019)$ \\
\hline \multirow[t]{2}{*}{ Has a lucky charm } & & -.0297 & -.0304 & & .0165 & .0199 & .0213 \\
\hline & & $(.0248)$ & $(.0249)$ & & $(.0282)$ & $(.0289)$ & $(.0292)$ \\
\hline \multirow[t]{2}{*}{ Belief that someone watches over them } & & .0144 & .0128 & & -.0089 & -.0157 & -.0148 \\
\hline & & $(.0219)$ & $(.0222)$ & & $(.0258)$ & $(.0259)$ & $(.0261)$ \\
\hline \multirow[t]{2}{*}{ Index: Good luck charms bring good luck } & & .0182 & .0189 & & .0217 & .0165 & .0174 \\
\hline & & $(.0107)$ & $(.0105)$ & & $(.0127)$ & $(.0120)$ & $(.0120)$ \\
\hline \multirow[t]{2}{*}{ How often person goes to church } & & -.0038 & -.0044 & & -.0047 & -.0080 & -.0071 \\
\hline & & $(.0065)$ & $(.0065)$ & & $(.0068)$ & $(.0072)$ & $(.0071)$ \\
\hline \multirow[t]{2}{*}{ Relative socio-economic status } & & -.0301 & -.0316 & & -.0263 & -.0371 & -.0335 \\
\hline & & $(.0180)$ & $(.0194)$ & & $(.0202)$ & $(.0213)$ & $(.0205)$ \\
\hline \multirow[t]{2}{*}{ Dummy for economists/finance students } & & .0036 & .0027 & & .0510 & .0299 & .0319 \\
\hline & & (.0308) & $(.0314)$ & & $(.0398)$ & $(.0430)$ & $(.0393)$ \\
\hline \multirow[t]{2}{*}{ Dummy for Engineering/IT students } & & .0960 & .0965 & & .1229 & .0924 & .0956 \\
\hline & & $(.0346)$ & $(.0348)$ & & $(.0438)$ & $(.0490)$ & $(.0464)$ \\
\hline \multirow[t]{2}{*}{ English is main language } & & -.0434 & -.0465 & & -.0380 & -.0490 & -.0421 \\
\hline & & $(.0299)$ & $(.0312)$ & & $(.0328)$ & $(.0373)$ & $(.0373)$ \\
\hline \multirow[t]{2}{*}{ Locus of control index } & & & -.0020 & & & .0038 & .0046 \\
\hline & & & $(.0033)$ & & & $(.0036)$ & $(.0035)$ \\
\hline \multirow[t]{2}{*}{ Satisfaction with financial situation (1-10) } & & & .0004 & & & -.0013 & -.0010 \\
\hline & & & $(.0044)$ & & & $(.0053)$ & $(.0052)$ \\
\hline \multirow[t]{2}{*}{ Satisfaction with all thing in life } & & & -.0064 & & & .0076 & .0103 \\
\hline & & & $(.0117)$ & & & $(.0146)$ & $(.0142)$ \\
\hline \multirow[t]{2}{*}{ Married } & & & .0108 & & & .0152 & .0129 \\
\hline & & & $(.0232)$ & & & $(.0262)$ & $(.0277)$ \\
\hline Time deciding sacrifice to Theoi & & & & & & & .0014 \\
\hline
\end{tabular}


Table 4. Proportion of Phase I sacrificed to Theoi (continued)

\begin{tabular}{|c|c|c|c|c|c|c|c|}
\hline Variable & Model 1 & Model 2 & Model 3 & Model 4 & Model 5 & Model 6 & Model 7 \\
\hline Contribution to PG game & & & & $\begin{array}{r}-.0001 \\
(.0000)\end{array}$ & $\begin{array}{r}-.0000 \\
(.0000)\end{array}$ & $\begin{array}{r}-.0000 \\
(.0000)\end{array}$ & $\begin{array}{r}-.0000 \\
(.0000)\end{array}$ \\
\hline Female & & & & & $\begin{array}{l}.0035 \\
(.0019)\end{array}$ & $\begin{array}{l}.0047 \\
(.0020)\end{array}$ & $\begin{array}{l}.0045 \\
(.0019)\end{array}$ \\
\hline Australian & & & & & $\begin{array}{l}.0023 \\
(.0024)\end{array}$ & $\begin{array}{l}.0016 \\
(.0025)\end{array}$ & $\begin{array}{l}.0016 \\
(.0024)\end{array}$ \\
\hline Age & & & & & $\begin{array}{r}-.0001 \\
(.0001)\end{array}$ & $\begin{array}{l}.0001 \\
(.0001)\end{array}$ & $\begin{array}{r}-.0000 \\
(.0001)\end{array}$ \\
\hline Has a lucky charm & & & & & $\begin{array}{l}-.0045 \\
(.0022)\end{array}$ & $\begin{array}{l}-.0049 \\
(.0023)\end{array}$ & $\begin{array}{l}-.0051 \\
(.0021)\end{array}$ \\
\hline Belief that someone watches over them & & & & & $\begin{array}{l}.0023 \\
(.0020)\end{array}$ & $\begin{array}{l}.0028 \\
(.0018)\end{array}$ & $\begin{array}{l}.0028 \\
(.0019)\end{array}$ \\
\hline Index: Good luck charms bring good luck & & & & & $\begin{array}{r}-.0003 \\
(.0009)\end{array}$ & $\begin{array}{l}.0002 \\
(.0009)\end{array}$ & $\begin{array}{l}.0002 \\
(.0009)\end{array}$ \\
\hline How often person goes to church & & & & & $\begin{array}{l}.0001 \\
(.0005)\end{array}$ & $\begin{array}{l}.0004 \\
(.0006)\end{array}$ & $\begin{array}{l}.0004 \\
(.0005)\end{array}$ \\
\hline Relative socio-economic status & & & & & $\begin{array}{r}-.0004 \\
(.0014)\end{array}$ & $\begin{array}{l}.0005 \\
(.0014)\end{array}$ & $\begin{array}{l}.0004 \\
(.0014)\end{array}$ \\
\hline $\begin{array}{l}\text { Dummy for economists and finance } \\
\text { students }\end{array}$ & & & & & $\begin{array}{r}-.0046 \\
(.0025)\end{array}$ & $\begin{array}{r}-.0026 \\
(.0026)\end{array}$ & $\begin{array}{r}-.0027 \\
(.0026)\end{array}$ \\
\hline Dummy for Engineering/IT students & & & & & $\begin{array}{r}-.0026 \\
(.0026)\end{array}$ & $\begin{array}{l}.0003 \\
(.0031)\end{array}$ & $\begin{array}{r}-.0003 \\
(.0031)\end{array}$ \\
\hline English is main language & & & & & $\begin{array}{r}-.0006 \\
(.0024)\end{array}$ & $\begin{array}{l}.0002 \\
(.0026)\end{array}$ & $\begin{array}{r}-.0002 \\
(.0027)\end{array}$ \\
\hline Locus of control index & & & & & & $\begin{array}{r}-.0006 \\
(.0002)\end{array}$ & $\begin{array}{r}-.0006 \\
(.0002)\end{array}$ \\
\hline $\begin{array}{l}\text { Satisfaction with financial situation (1 to } \\
\text { 10) }\end{array}$ & & & & & & $\begin{array}{l}.0002 \\
(.0004)\end{array}$ & $\begin{array}{l}.0002 \\
(.0004)\end{array}$ \\
\hline Satisfaction with all thing in life & & & & & & $\begin{array}{r}-.0013 \\
(.0010)\end{array}$ & $\begin{array}{r}-.0016 \\
(.0009)\end{array}$ \\
\hline Married & & & & & & $\begin{array}{r}-.0005 \\
(.0021)\end{array}$ & $\begin{array}{r}-.0000 \\
(.0020)\end{array}$ \\
\hline Time deciding sacrifice to Theoi & & & & & & & $\begin{array}{l}.0004 \\
(.0001)\end{array}$ \\
\hline Number of observations & 7020 & 7020 & 7020 & 7020 & 7020 & 7020 & 7020 \\
\hline Sigma & .2953 & .2925 & .2923 & .2949 & .2913 & .2908 & .2897 \\
\hline Pseudo R2 & .2575 & .2915 & .2924 & .2596 & .3027 & .3063 & .3170 \\
\hline
\end{tabular}

Standard errors in parentheses. 


\section{Figure 1. Average investment to group project and proportion of Phase I's earnings contributed to Theoi}
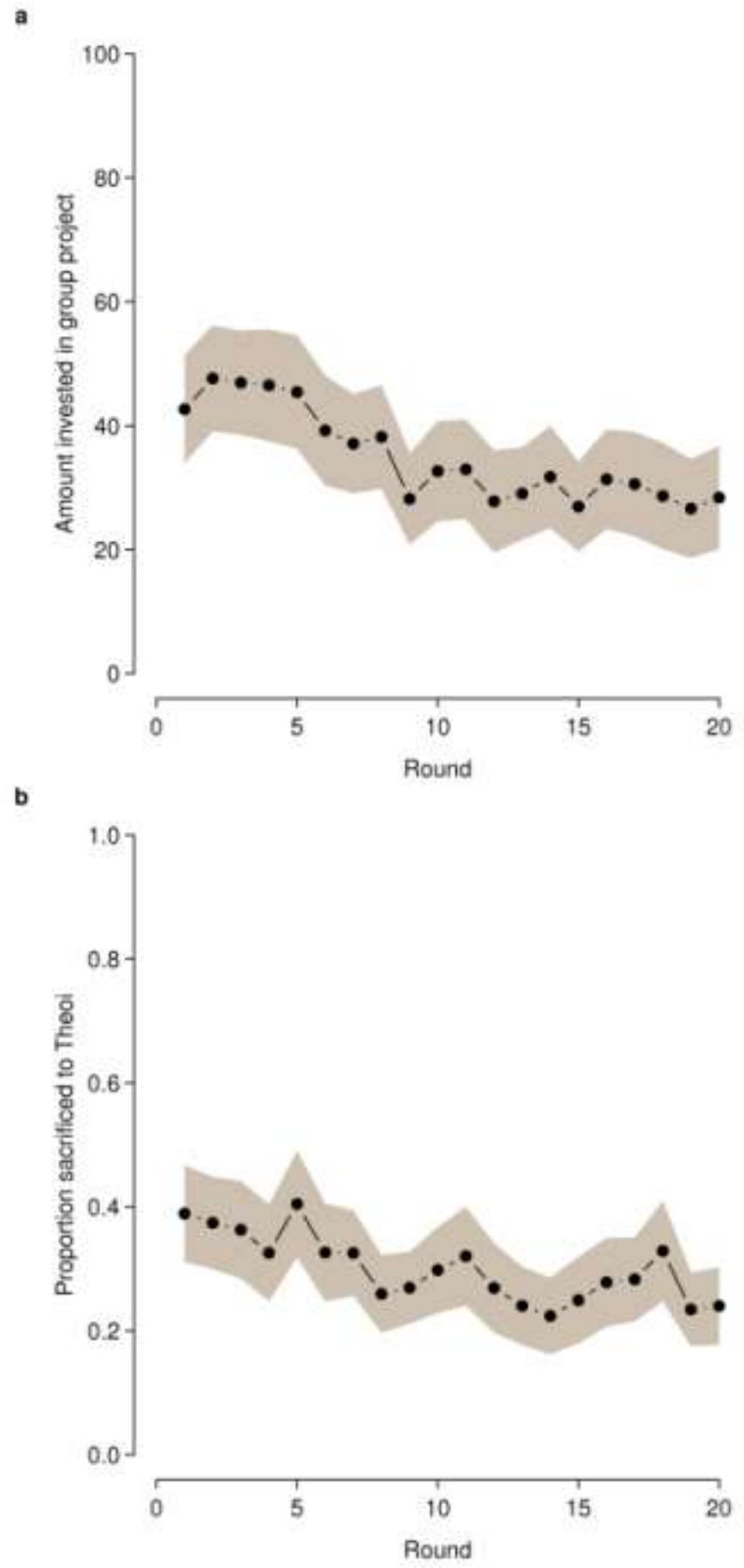

Notes:

(a) Average investment to the group project. This treatment was applied in 4 sessions. A total of 56 individuals participated in these sessions. Shaded grey regions show the 95\% normal confidence intervals. (b) Average contribution to Theoi as a proportion of Phase I earnings. In this treatment the unit value is determined as $\max (0,1+$ individual shock + group shock $)$. The group and individual shocks are drawn from uniform distributions in the interval $(-1,1)$. In periods 5,10 and 15 the group shock equals -0.5 . This treatment was applied in 4 sessions. A total of 56 individuals participated in these sessions. 
Figure 2. Baseline versus no-uncertainty treatment

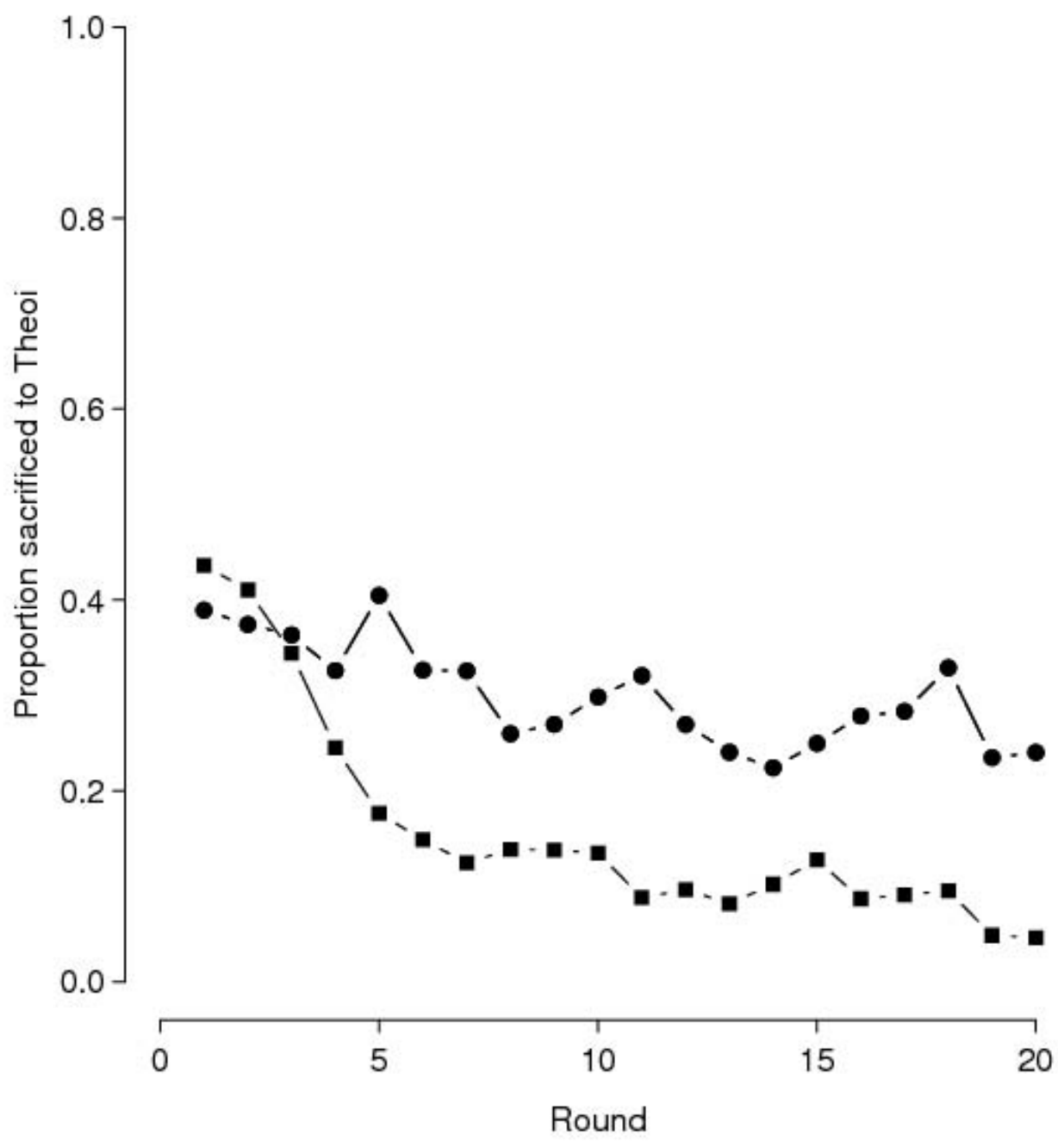

Note: Average contribution to Theoi as a proportion of Phase I earnings. Shaded grey regions show the 95\% normal confidence intervals. This treatment was applied in one session. A total of 17 individuals participated in this session. The average invested in the group project is not shown but is similar to the one in the baseline treatment. In this treatment the only source of uncertainty is the group shock, except in periods 5,10 and 15 when it equals -0.5 . 


\section{Figure 3. Average sacrifice when uncertainty is high and sacrifice is made to the weather}

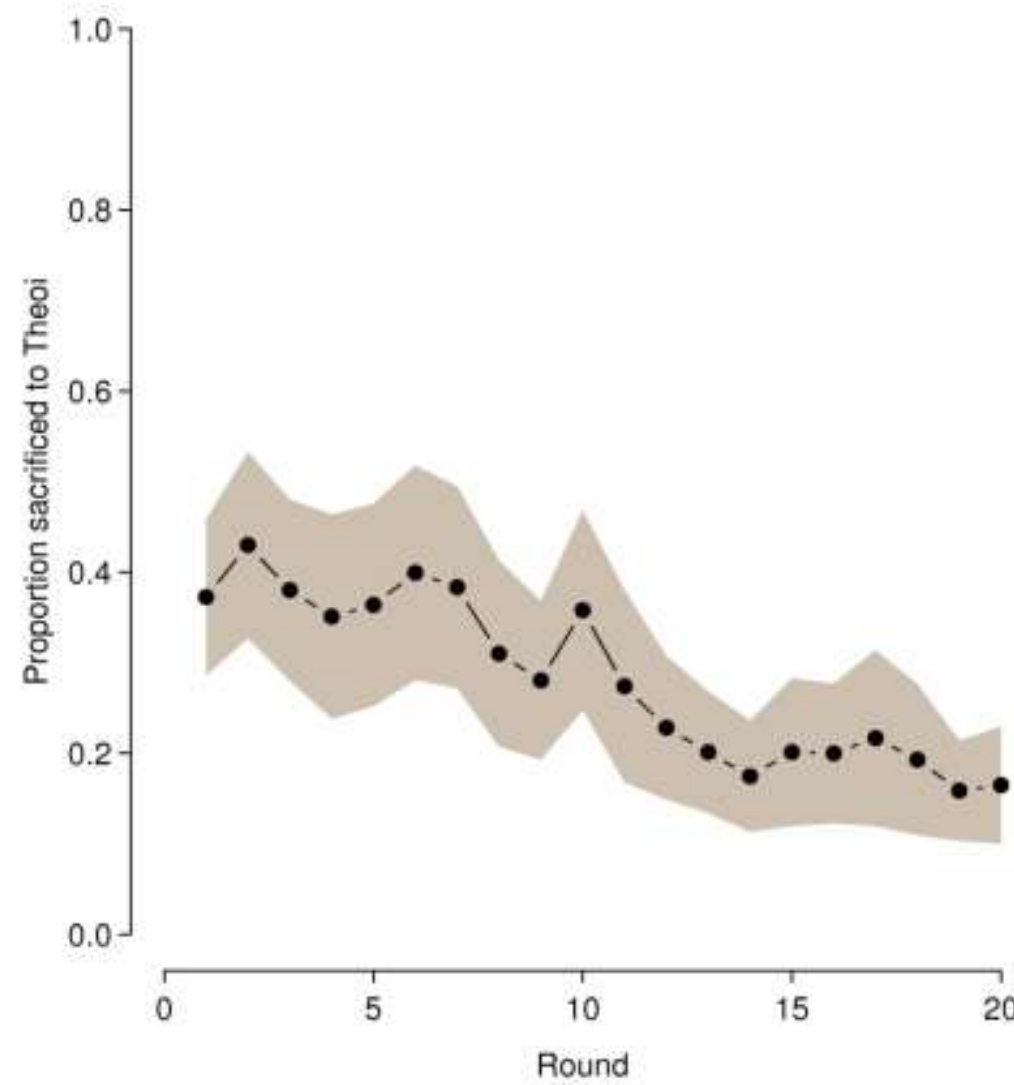

Note:

Average contribution to the weather as a proportion of Phase I earnings. Shaded grey regions show the $95 \%$ normal confidence intervals. In this treatment the unit value is determined as:

$$
\max (0,1+\text { individual shock }+ \text { group shock }) \text {. }
$$

The group and individual shocks are drawn from uniform distributions in the interval $(-1,1)$. In periods 5,10 and 15 the group shock equals -0.5 . This treatment only differs from the baseline experiment in that individuals are given the option to sacrifice to "the weather" instead of sacrificing to Theoi. This treatment was applied in two sessions. A total of 32 individuals participated in these sessions. 


\section{Figure 4. Average sacrifice when uncertainty is high and individuals can share information}

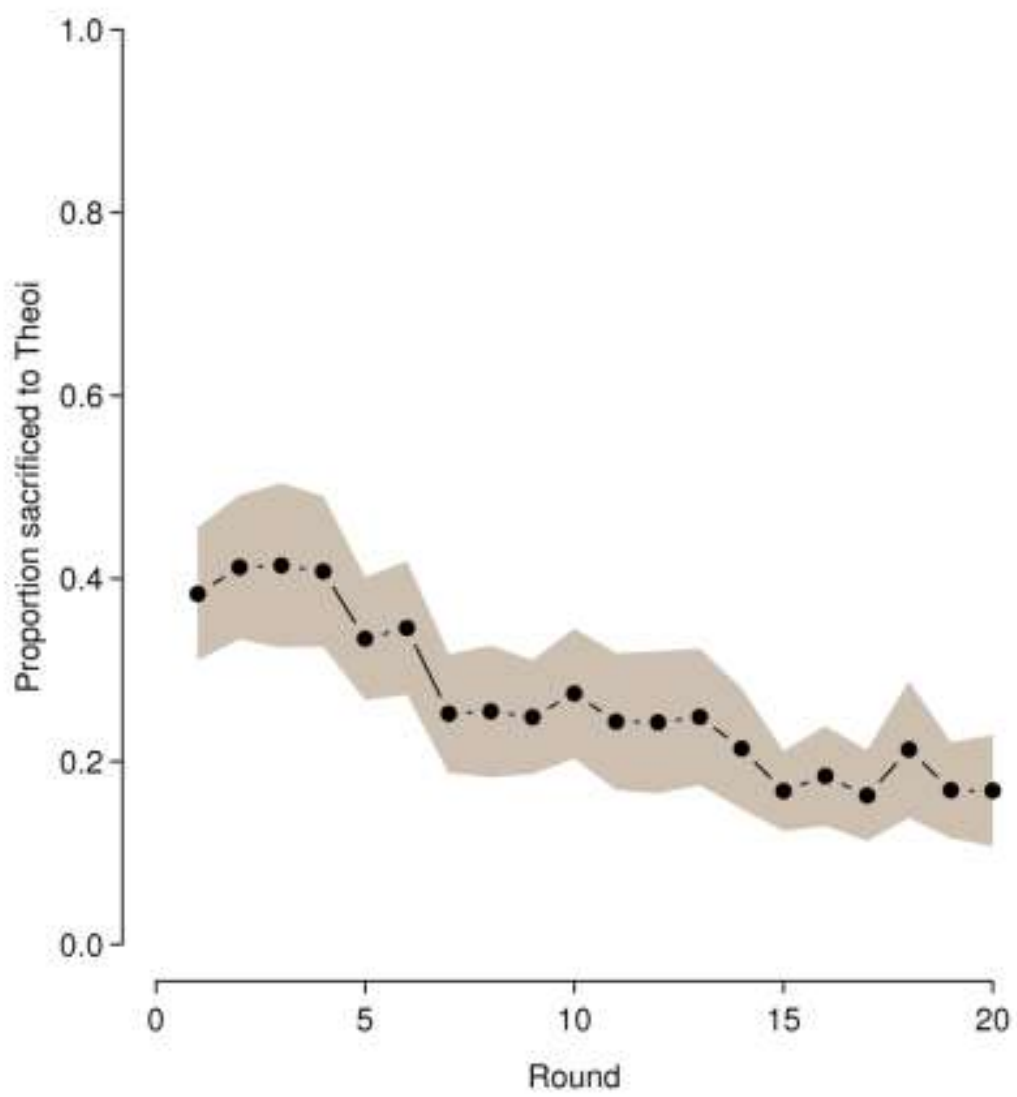

Notes:

Average contribution to Theoi as a proportion of Phase I earnings. Shaded grey regions show the $95 \%$ normal confidence intervals. In this treatment the unit value is determined as:

$$
\max (0,1+\text { individual shock }+ \text { group shock }) \text {. }
$$

The group and individual shocks are drawn from uniform distributions in the interval $(-1,1)$. In periods 5,10 and 15 the group shock equals -0.5. This treatment differs from the baseline experiment, in that individuals were allowed to reveal their absolute sacrifice to Theoi and the unit value they obtained to all other participants in the session. This treatment was applied in three sessions. A total of 53 individuals participated in these sessions. 
Figure 5. Distribution of the spread in sacrifices across individuals

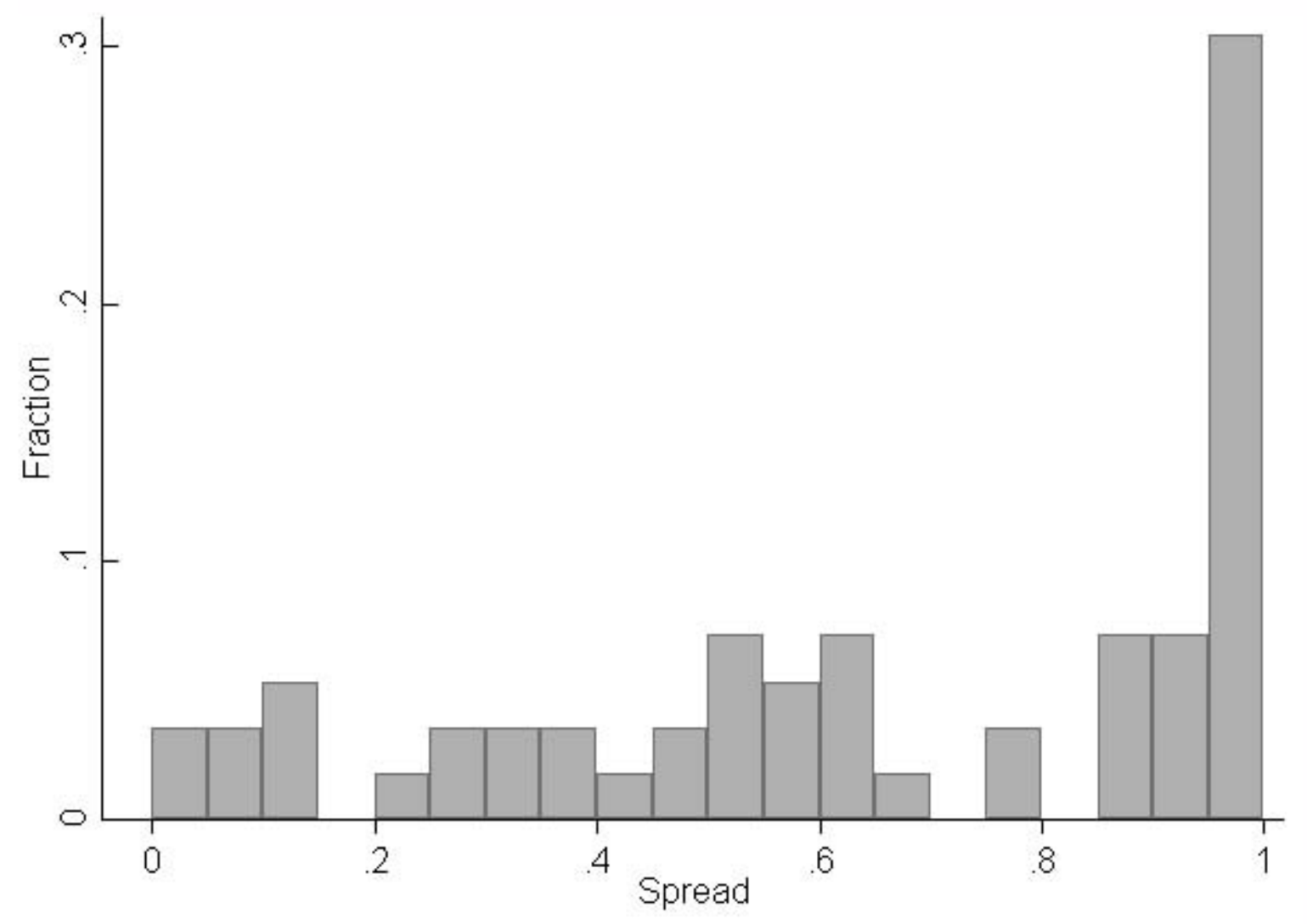

Notes: The Bandwidth is 0.05 . 